\title{
Productive spending of the child's time
}

\author{
Adilova Feruza Oblokulovna \\ (Samarkand State University) Correspondence Department Assistant \\ adilova.feruza@bk.ru
}

\begin{abstract}
Harmoniously developed children's school of out-of-school education enriches the imagination of our children to think freely, choose the right profession, develop fine motor skills.

Keywords: proper organization of children's leisure time, use of STEAM program, proper orientation of gifted children.
\end{abstract}

\section{I.Introduction}

Child- family joy, the base of society. The fact that the child is healthy, educated and strong-willed is not only a parent, but also one of the noble goals of the policy of our state. Therefore, from the early days of independence in our country, high attention and care are being paid to the younger generation.

Young people of our country are working with enthusiasm in various spheres of our life today. They are today students and readers, workers and doctors, educators and engineers and entrepreneurs. Our young people perfectly master computers, internet techniques, several foreign languages, study in developed countries and enter the world arena.

From the first days of our independence, radical reform of the educational system, decent upbringing of a harmonious generation was defined as one of the priority tasks. And this, in its place, has a positive effect on the quality of Education. After all, the fact that the younger generation is brought up on the basis of the ideas of independence, the worthy maturation of our great ancestors depends, first of all, on the lessons that the teacher gives, on his research and aspiration. It is not surprising that enthusiastic, knowledgeable, highly intelligent specialists make a huge contribution to the development of the industry.

As a result of the introduction of the system of continuous education in our country, it became a common goal to educate an independent - minded, self-sufficient person capable of fully manifesting his mind, thinking and potential, responsible, having a broad outlook, free and free-thinking person.

Priority attention is paid to the creation of the necessary conditions for the emergence of intellectual potential, inner strength and talent in each child. This will serve as a solid foundation for our children to be raised physically, mentally and spiritually from the age of infancy to adulthood, based on a clearly targeted program. The main subject of methodological provision in extracurricular educational institutions is pedagogical activity, which must attach great importance to the pedagogical system in the educational and educational process. Growing on the path of building a legal democratic society, Uzbekistan attaches great importance to the fact that from the first years of its independence it has grown to become a mature generation, capable of educating young people, becoming educated and meeting the requirements of the standards of world education in the future, being able to compete with the youth of developed countries. Of course, such a great goal, lessons taken to secondary schools in the implementation of tasks, practical work are of great importance. Because the occurrence of any aspirations, dreams, intentions and aspirations of children most of all go to the formation of this classroom activity. The state system and social system, which includes the networks of extracurricular educational institutions, the mass media, the social movement of the organization of work with children in their places of residence, are of great help to the school.

In Uzbekistan, serious attention was paid to the development of the system of extracurricular education. In accordance with Article 17 of the law "on education" of the Republic of Uzbekistan, it was noted that it is desirable "to organize extracurricular educational institutions in the fields of mine-aesthetic, scientific technical, sports and other spheres" for the purpose of satisfying the individual needs of children and adolescents, organizing their free time and leisure activities, as well as other legal and physical persons.

Extracurricular education on the basis of additional educational programs is a pedagogical process aimed at satisfying the existing needs of students, organizing their leisure time and leisure activities, it was organized palaces of creativity of children (adolescents), homes, sports schools of children and adolescents, art schools, music schools, health centers. The relevance of extracurricular activities today is that, in the first place will prevent unemployment, that is, in addition to the school textbook, it is also at home to engage in any training and if our young people, who are currently limited to school textbooks, are attracted to training according to their interests, then the interest of students in the choice of a profession in the future will increase and they grow as mature specialists of the chosen profession.

At the same time, there are opportunities for students and young people to voluntarily study in extracurricular educational institutions and actively participate in circles of their interest in the areas of artistic and technical creativity, tourism, local development, sports.

Abu Rayhon Beruni, a famous scholar of the East, said: "Our goal is not to make the reader tired. It will always 
be boring to read something and will make endure. If the reader passes from one issue to another, it will be as if he is traveling in different garden rinks, as soon as he passes through one garden, another garden will begin. A person will come to see and watch them all. Every new thing brings pleasure". Therefore, in our homeland, a perfect human upbringing, which in all respects brings the younger generation to the level of a perfect person, is a complex work, which has risen to the level of state policy.

It is known that students will have 5-6 hours of free time every day except for school. In such free time it is desirable to organize with young people all kinds of educational work, both from class and out-of-school. Classroom and extracurricular activities in general are of paramount importance in the proper and efficient use of students' free time. Extracurricular institutions have always complemented the educational process of secondary schools in the organizational, methodical activities of their education.

The number of educational work carried out in extracurricular educational institutions- this is not to ignore the attention paid to the education of schoolchildren in their spare time, interesting and their ability to spend their free time of youth without making them meaningful, boring, to lead in the direction of the progress of the spiritual world and to raise their activity, initiative to new levels, practical application of theoretical knowledge gained in schools, to test himself in practice in any field of his choice by even more intensifying his enthusiasm for science and technology, it is an expression from the complex of such works as raising creative abilities, making healthy and full-fledged people of our independent homeland. Extracurricular educational institutions create the first conditions for students' interest in the choice of profession to test their theoretical knowledge gained in schools practically, in connection with the production process, the formation of their qualifications.

At present, on the basis of the latest achievements of science and culture, the search for effective types and methods of preparing the younger generation for life, which is the foundation of our future, is the most important task. In this regard, increasing the effectiveness of extracurricular educational work depends primarily on our search for modern and convenient directions of formation of a harmonious person and its application in practice.

According to Abu Rayhon Beruni, the great scientist of the East: "The time ladder is endless, generations that take the place of one another rise up from the stairs to the stairs, no more. The accumulated experience is delivered by each generation to the next generation, which comes after it, develops and enriches it after itself'.

We often realize late that our child is talented, talented, without parents knowing it ourselves. How will it be correct for them to grow up as a harmonious person? Most parents say that the younger the children, the younger still go to the pre-school institution, or if the school passes from the primary class to the upper class and then participates in any circle, then you have created laziness disease to your child, without knowing it yourself. Our great ancestors expressed valuable thoughts about the need to learn about labor and craft. For example, Abdurahman Jami said so: "Do not find gold, learn craft, cross in front of craft gold-dice". And also the great thinker Alisher Navoi said:" Do not waste your life, work, know the key to happiness.".

Bring your child to the mounds and make it possible for them to grow up as a harmonious person. What is actually the hog itself?, why do you need it? Additional training- this is an exercise that is aimed at meaningful spending the free time of each child, this is the first step in the process to choose the training of the big interested in the child himself. Of course, the child feels free, learns to do any work as a team until the end, is spiritually and heartily delighted with the work he or she has done. At present, parents or adolescents themselves attend language courses. Proper language would be an excellent light upon light if the language is learned well and at the same time the craft is also learned. In us there are children's schools of a harmonious generation for artistry. There are training sessions in different directions, in which our sons and daughters from 6 to 18 years old are trained in different directions and show their talents and abilities. If your children are attending classes, where are they after their school? With whom? You will be far from the various unpleasant fantasies.

Children who have participated in additional classes enjoy the work they have created, are searched for the desired result, work, read books to become a master of the skill of the work they are studying without knowing it, even if they are not interested in reading books. It will display the closed edges in the direction they choose.

For elementary school students, the circle forms the students' fine motor skills. If he participates in such circles, then in the upper class he chooses for himself the necessary circle, and in this the labor productivity is higher.

Any circle work is not included in the compulsory school curriculum. It is carried out by teachers in order to improve the knowledge of children in terms of directions. Participation in the circle will create a basis for choosing the right profession in the future.

Regardless of its direction, the circle receives joy from the collective work of the children, directing them to a specific goal, nurturing love for labor, and thereby developing the ability. It is also a useful lesson for schoolchildren who do not know the time, price of the circle - passing. Children who participate in gangs are not capable of crime, and they are workers.

The president of our country Mirziyoyev Shavkat Miromonovich adopted a decision on the establishment of children's schools of a harmonious generation. According to the resolution, in 2020-2023, "children's tourist bases" for 100-200 seats will be established in the presence of children's schools of "harmonious generation" in Bukhara, 
Kashkadarya, Namangan, Samarkand, Khorezm regions and Tashkent City. From the 2020/2021 school year in children's schools" harmonious generation "STEAM-education" program will be introduced.

\section{Beginner technical modeling-what is it?}

In the initial technical modeling circle, boys and girls are accepted from the age of 6 years, in which children learn to draw, shave, glue. During the circle training, the maturation of the hands develops new ideas are formed and the circle of thinking grows. In the first academic year of the circle, children are made up of different things constructors through ready-made Lego's, different things from colored paper, cardboard fruits on the basis of pictures from pieces of colored paper, animals are made through pieces of colored paper, which are ground and scraped, drawing drawings of different sizes. If one learns to draw geometric figures and make clippings, then in the second school year they learn to make models of different things based on the geometric shapes made. They invent different things, for example , using triangles, rectangles, prisms, cones, pyramids, slindr and other shapes from the geometrical shapes that are laid out. The center for children of the adolescent generation is now a school of children of the adolescent generation, which began its activity on the basis of the STEAM-education program. In the STEAM - education program, lessons in the field of Natural Sciences (Science), Technology, technical creativity (Engineering), art, mathematics are taught in English. Technical creativity in the program" STEAM-education " is the first stage of this after the initial round of technical modeling, they can continue the round in the areas of robotics, automodel, aviomodel, shipbuilding, computer graphics and design architecture.

Simply on the ground of the initial technical modeling circle, many inventions come into being. Children in the elementary class, that is, from the 1 class they themselves can do technology lessons well. Later interest in the same sciences will increase as Labor, fine arts, mathematics, geometry, drawing, Physics, Chemical sciences will become a link.

\section{LIST OF LITERATURE}

\# O’zbekiston Respublikasi Kostitusiyasi. T.: O’zbekiston, 1992.

* O’zbekiston Respublikasi. "Kadrlar tayyorlash milliy dasturi”. -T.: 1997.

* O’zbekiston Respublikasining “Ta'lim to'g'risida”gi qonun Barkamol avlod O’zbekiston taraqqiyotining poydevori. T.:1997

* Karimov.I.A Yuksak ma’naviyat -yengilmas kuch.-T: "Ma’naviyat”,2008

* Mirziyoyev Sh.M tomonidan Barkamol avlod bolalar maktablarini tashkil etish to'g'risidagi qarori

\# Beruniy Abu Rayhon.Tanlangan asarlar.-T.: fan,1982.-344b.

* Khudayberganova, G. N. (2019). АНАЛИЗ ФЕНОМЕНА АСКЕТИЗМА В УЧЕНИЯХ МИРОВЫХ РЕЛИГИЙ. Theoretical \& Applied Science, (12), 579-582.

* Alimova, M., \& Nigmatullayev, I. (2019). CLARIFICATION OF TOLERANCE IN ISLAMIC SOURCES. The Light of Islam, 2019(1), 13.

* Alimova, M. (2019). ACTUAL DEVELOPMENT TRENDS OF RELIGIOUS STUDIES IN UZBEKISTAN. The Light of Islam, 2019(4), 42.

* Alimova, M. (2020). THE CONTRIBUTION OF IMAM AD-DARIMI TO THE DEVELOPMENT OF HADITH SCIENCE. The Light of Islam, 2020(2), 109-116. 